\title{
Folate Receptor Beta
}

National Cancer Institute

\section{Source}

National Cancer Institute. Folate Receptor Beta. NCI Thesaurus. Code C104916.

Folate receptor beta ( $255 \mathrm{aa}, \sim 29 \mathrm{kDa}$ ) is encoded by the human FOLR2 gene. This protein is involved in folic acid transport. 